\title{
PEER LEARNING-BASED STRATEGY IN EFL READING CLASSROOM
}

\author{
Juang Kurniawan Syahruzah \\ Universitas PGRI Yogyakarta \\ juang@upy.ac.id
}

\begin{abstract}
The intention of this study is to describe the effectiveness of peer learning in EFL reading classroom of English Department students of PGRI University. The comprehension analysis is intended by comparing the answer of EFL reading classroom students in reading exercises. In order to sequence the reading comprehension of the EFL reading classroom the pre-test and post-test of reading exercises are measured. The experiment of reading comprehension includes the recruitment of 40 students of EFL reading classroom, the training, and exercising of reading text in reading exercises. These students are all first-year female teacher training students at PBI-UPY and aged between 17 and 23. The measurement is compare with pre-test and post-test of reading exercises. Standard measurement is comparison of students answer in pre-test and post-test of reading exercises. The result of this research the students who passed the standard score improved from $37 \%$ in the preliminary data to $77 \%$ at the end of the research. It means that peer learning strategy improves students' reading comprehension that was influenced by student's factors (attention, interest and participation) and lecturer factors (choosing the material and managing classroom).
\end{abstract}

Keywords: peer learning based, EFL, non-native reading comprehension

\section{CHAPTER 1 INTRODUCTION 1.1. Background of the Study}

Students in Indonesia are brought up by families who live in a country where various forms of social and political inequality are experienced, a reality that is not different in any other country. In such a sociopolitical environment, a world view is always attached to the values or knowledge pieces given to these students. Marx (1968: 183) states that "it is not the consciousness of men that determines their being, but, one the contrary, their social being that determines their consciousness.

The combination of the aforementioned reality with Marx' statement leads us to the conclusion that the social being constructed in families and through schooling feeds the consciousness of the student, thus, real change towards creating a just society is becoming more and more difficult since the formation of the mind of the youth by family and schooling happens between what we may call through the famous pendulum effect. In short, the writer argue that the harmful effects of TV shows, newspapers, political agenda of various neo-liberal conservative political parties on family and social values is constantly supported by course books, leaving almost no place to experience and examine alternative ways of re-structuring the social environment.

This situation is most tense when the recent increase in nationalist spirit pumped into teenagers is examined. As a teacher educator, the writer note that although it is more difficult now to set up critical education in classrooms, the need for such an activity is even more pressing. As such, the writer start my work with the course books with which we teach, to examine what kind of a world is tailored for my students. This resistant activity is first pedagogically important because the preservice teachers with whom the writer study gain a lot of insight through such activity which as Kincheloe (2004) claims to "resist dominant power by exposing and subverting it within schools."

Similar to many teachers of English as a foreign or second language, I have used numerous course books not only to follow administrative decisions, but also because 
of my belief grounded in my experiences with course books as valuable instructional materials. As my experiences suggest, course books present a smooth-running curricular program for the teaching of the essential and necessary items of the language taught with which one cannot lose his or her way as a teacher. Course books still continue to be the single most important resource in the language classroom throughout the world. Hence, the importance of course books in the professional lives of the ELT practitioners is obvious. In many classrooms, course books and their components make up the only instructional material used in the classroom..

The on-line voting system opened by $\mathrm{BBC}$ collects ELT practitioners views on the frequency of ELT teachers' use of course books and shows that about only $6 \%$ of the 310 voters claim that they never use course books in their classrooms although those claim that they use course books more than half of the classroom time makes up $79 \%$ of the teachers.

(See:

http://www.teachingenglish.org.uk/talk/vote /vote4_coursebooks.shtml).

It was long after the writer started teaching and using course booksthe writer noticed and verbalized that teaching with course books had another advantage which was that course books expanded our general knowledge more than any material or activity with which we were engaged within or outside our classrooms. As teachers of English, we are able to talk about tourism, foods, habits, culture and history, and psychology-especially with the knowledge we get from our course books. It can also be said that as foreign language teachers, we have a unique chance of facing multiplicity of topics on our daily activities since the course books we use are full of a variety of topics of reading passages. The help we get from our course books is beneficial, simply because we are aware that, as can be seen in the words of Stubbs (1982:138), English teachers have always been 'responsible not only for the linguistic development of their pupils, but also for their psychological, moral and interpersonal development-and to expect them also to provide a world view and philosophy of life.' In short, course books are not instructional materials only, but they are sources of knowledge and information on various aspects of individual and societal phenomena.

\subsection{Formulation of the Problem}

This study will explorereading comprehension of EFL students and to try to answer two questions:

1. Does peer learning-based enhance the reading ability of EFL college students?

2. How is the effectiveness of reading strategy training related to the reading proficiency of the students?

\subsection{Research Outputs}

The experimental research has following outputs:

1. This model of measurement can be applied in teaching reading.

2. This study offers variety of teaching learning process in reading classroom.

3. Describe the difficulty and also the solution in EFL reading classroom.

\subsection{Objectives of the Study}

Theobjectives of the study are mentioned as follows:

1. To describe the improvement of reading proficiency.

2. To figure out the effectiveness of peer learning-based in EFL reading class.

\subsection{Significances of the Study}

The significances of this study are:

1. Teachers are able to measure the level of students' proficiency in reading comprehension.

2. Students are able to improve their ability and skill in reading comprehension.

\subsection{Hypothesis}

The proposed hypotheses in this study are:

1. EFL students will be better in reading comprehension due to the process of peer learning-based as a teaching learning process in reading class.

2. Since the applied of the strategy the students will get easier understand of text in English. 
CHAPTER 2 PREVIOUS STUDIES AND THEORETICAL REVIEW

\subsection{Previous Studies}

Previous works related to the English reading comprehension more specifically in reading strategy in many countries in which English is still considered as a second or foreign language. Many scholars have described the strategy to improve reading comprehension for EFL students. Nonetheless, Studies aboutreading strategy in improving reading comprehension has rarely been conducted by Javanese or Indonesian teacher. In Indonesia, studies about reading strategy are focus on the same strategy with different subjects. There are only few researches related to the study.

Alfiyani (2012)writes about the use of metacognitive strategy in teaching reading for the eleventh grade students of SMAN 2 Kudus. She finds that the reading ability of the eleventh grade students of SMA N 2 Kudus in the academic year 2011/2012 after being taught by using Metacognitive Strategy is better than the reading ability of the eleventh grade students of SMA $\mathrm{N} 2$ Kudus in the academic year 2011/2012 before being taught by using Metacognitive Strategy. Another Indonesian researcher, Galih (2010) writes about SQ3R reading strategy helps tenth graders of SMA Negeri 1 Srengat, Blitar, East Java to solve their problems in reading descriptive texts. $\mathrm{He}$ finds that SQ3R reading strategy could help improve the students' ability in reading descriptive texts by providing a structured approach for reading activities.

According to the previous explanation, in Indonesia, researches related to reading strategy in improving reading comprehensionof English as a second language have rarely been done.English reading strategy of Indonesian learners is an interesting topic to study for researchers. Thus, it can be concluded that this research is relatively new and needs to be conducted. This research will give novel contribution to ELT and other second language learning in Indonesia.

\subsection{Theoretical Framework}

\subsubsection{Basic Concept of Reading}

Teaching EFL reading is a bit different than the way native speakers are taught to read. While vocabulary is an important part of reading, teaching the reading skills of surveying, skimming, scanning, inference, predicting and guessing are just as important.Research tends to indicate that a student's reading comprehension can be improved by focusing on teaching students skills in the following areas:

\section{a. Vocabulary}

Many languages do not have the word building concepts that English does. In teaching vocabulary, the idea of "root" words and prefixes and suffixes helps students build a larger vocabulary quickly. Affixes (prefixes and suffixes) help us create a variety of words from one base word. Many EFL students won't recognize that contain is the root word of container and containment or that desire is the root word of undesirable and desirability. When teaching new vocabulary, it is important to point out these connections and we can quickly help students expand their vocabulary with the base words they already know. Teaching affixes is only one of several strategies for teaching vocabulary. See the links below for more.

\section{b. Surveying, Scanning, Skimming}

In an academic setting, we rarely read an entire text word for word. More typical is that we look at the contents of a book, the chapters, headings, subheadings, sidebars, pictures, illustrations, words in italics and bold type and dive in to find the information we need. These are the concepts of surveying, scanning and skimming, moving from the big ideas of a text down to the specific details. These are skills that EFL students don't usually have and must be taught. The linked readings for teaching EFL reading below will give you more specifics on these skills.

\section{c. Guessing and Predicting from Context}

Students also need to be taught to guess the meanings of words based on 
the context of the reading and to draw from the reading an ability to predict what might happen in the next paragraph. Links below will lead to more information on these skills.

\subsubsection{Teaching Reading}

For the right focus in the teaching of reading, it is important to define it and closely examine what problems students face while reading something in English. It is difficult to define reading in a word. Many thinkers have defined and analyzed it in many different ways. The perspective of reading differs from person to person depending on the person's individual attitude and aims towards printed words, from language to language considering the cause of reading and the content of the text. So,the definition and meaning of reading depend, largely, on the purpose of the reader, on the text and textual contents, on the attitude of the readers towards the text, on the reading materials and on the experience and schemata of the reader. However, experts have tried to define it differently, in their own way of observation and thought.

Some argue that reading is a conceptual and thinking process through print, and the process is interpretative (Emarald et al.: 1982). Widdowson (1979) is of the same opinion that reading is the "process of getting linguistic information via print."Ransom (1978: 14-15) defines reading as 'a conversation' between the writer and the reader. He states that like someone who is talking, "the writer is trying to convey some message to another person." Shaw (1959: viii) also states that reading is the communication of thoughts, moods, and emotions through which one receives 'from others their ideas and feelings'. Nuttall (1996: 4) regards reading as the process of "getting out of the text as nearly as possible the message the writer put into it."Williams (1996: 2) states reading as 'a process' through which one looks at and understands a written text. Goodman (1967) defines reading as a 'psychological guessing game', and
Patricia Carrel et al (1988) define reading as an 'interactive process' where readers employ their background knowledge and past experience to make sense of the text. Reading, according to Moynihan (1969: 267), "frequently uses chronology, comparison-contrast, causality, and analogy."

This process is precisely active (Doff, 1997: 67; and Rauch et al. 1968) and cognitive (Urquhart and Weir, 1998: 17), and the reader in a contact with the text carries it out (op. cit.). Grellet (1996: 8) defines reading as 'an active skill'. Rauch and Weinstein (1968) terms reading as an active, alert thinking process "where the reader matches the writer thought for thought." According to Shaw (1959: viii) reading is "thinking with the author, absorbing his ideas."Urquhart and Weir (1998: 22) have tried to give a precise, shortcut and acceptable definition of reading after observing and analyzing the definition of others. According to them, reading "is the process of receiving and interpreting information encoded in language form via the medium of print."

\subsubsection{Peer Learning}

Peer learning is not a single, undifferentiated educational strategy. It encompasses a broad sweep of activities. For example, researchers from the University of Ulster identified 10 different models of peer learning (Griffiths, Housten and Lazenbatt, 1995). These ranged from the traditional proctor model, in which senior students tutor junior students, to the more innovative learning cells, in which students in the same year form partnerships to assist each other with both course content and personal concerns. Other models involved discussion seminars, private study groups, parrainage (a buddy system) or counseling, peer-assessment schemes, collaborative project or laboratory work, projects in different sized (cascading) groups, workplace mentoring and community activities.

For peer learning to be effective, the teacher must ensure that the entire 
group experiences 'positive interdependence', face-to-face interaction, group processing, and individual and group accountability. 'Positive interdependence' emphasises the importance and uniqueness of each group member's efforts while important cognitive activities and interpersonal dynamics are quietly at work. As students communicate with one another, they inevitably assume leadership roles, acquire conflict-managing skills, discuss and clarify concepts, and unravel the complexities of human relationships within a given context; this process enhances their learning outcomes.

Thus, students' learning extends far beyond the written word and even the given task. However, peer learning may encourage the presence of 'freeloaders'team members who fail to fulfill their team responsibilities, but are awarded for assignments or presentations the same (high) grade as their more responsible teammates. Freeloading may be minimized by using peer ratings to assess individual performance of team members, or conducting a 'post-test'. There will then be two levels of accountability: the individual and the group..

To facilitate successful peer learning, teachers may choose from an array of strategies:

a. Buzz Groups: A large group of students is subdivided into smaller groups of 4-5 students to consider the issues surrounding a problem. After about 20 minutes of discussion, one member of each sub-group presents the findings of the sub-group to the whole group.

b. Affinity Groups: Groups of 4-5 students are each assigned particular tasks to work on outside of formal contact time. At the next formal meeting with the teacher, the subgroup, or a group representative, presents the sub-group's findings to the whole tutorial group.

c. Solution and Critic Groups: One sub-group is assigned a discussion topic for a tutorial and the other groups constitute 'critics' who observe, offer comments and evaluate the subgroup's presentation.

d. 'Teach-Write-Discuss': At the end of a unit of instruction, students have to answer short questions and justify their answers. After working on the questions individually, students compare their answers with each other's. A whole-class discussion

\section{CHAPTER 3 METHOD}

\subsection{Subjects}

This experimental research involves forty subjects who are native speakers of many regions in Indonesia (EFL) aged 17-23. They use mainly their mother tongue in daily communication and live in Yogyakarta. In addition, they have never been to English speaking countries. The subjects are all students of English Department of University of PGRI Yogyakarta (PBI-UPY) and all subjects have been studying English for at least a half years. To ease the training process, the subjects will be informed that the pre-test and post-test will be used for educational and experimental purposes.

\subsection{Materials}

The subjects had the reading exercises, which had been provided by the lecturer; however, lecturer was allowed to use any textbooks and materials and to develop their own tests. Therefore, the researcher selected twelve reading passages which would be covered during the semester from a variety of sources. Five reading passages were drawn from the subjects' textbook, and seven reading passages from popular writings or ESL reading materials. The reading passages were chosen on the basis of subjects' presumed interest and for their readability.

The strategy training procedure used in this study is peer learning-based. All of the reading lessons given in this study were conducted in Indonesian. Prior to the training, the researcher and the class had general discussion about strategic learning and strategic reading. In the discussion, reading strategies and strategic reading were defined. The writer explained and the class discussed why learning and practicing effective is important. Through 
this discussion, the subjects were informed of the following points: first, strategies help to improve reading comprehension; second, strategies also help enhance efficiency in reading; third, students will be reading in the way that expert readers do; finally, strategies help students to process the text actively, to monitor their comprehension. The writer used this type of discussion not just in initial class periods, but also on a recurring basis to make sure that students were aware of the importance and value of what they were doing.

\subsection{Reading Test Procedure}

In addition, the writer clearly and explicitly explained the specific procedure of the training method and its benefit. Next, the writer conducted peer learning-based activities in order to activate students' background knowledge related to the topic and content of the reading passage. After that, the writer asked the students to read silently the assigned section of the passage. In the beginning, the students were given enough time to read an assigned section of a passage; however, as time went by, they were gradually given less reading time.

When the students finished this task, the writer modeled the following reading strategies: first, the writer summarized the section of the passage; second, the writer composed a couple of questions on the content of the section; third, the writer predicted the content of the following sections; finally, the writer critically evaluated the content for internal consistency and compatibility with prior knowledge and common sense, discussing the points that needed to be clarified. Although most lessons were focused on the four activities, the writer sometimes modeled other strategies, which are also important in comprehending a text, when they were relevant to the passage: understanding rhetorical structures, guessing the meaning of unfamiliar words from context, skimming, etc. In modeling the strategies, the writer read aloud the portion of the passage, and when she did so, she used the "think aloud" technique. The writer always tried to provide concrete examples in order to show the students clearly which strategies are useful, how they are used, and why they are helpful.

From the very beginning, students were encouraged to participate at whatever level they could thoughthe writer expected that familiarity with this process would take time. In the initial phase of the training, therefore, students were relatively passive observers. However, when the writer felt that the students were capable of performing the four activities, she encouraged the students to participate in the four activities more actively. Some students successfully summarized a portion of the passage with or without the writer's help; some students predicted the general content of the following paragraphs. From time to time, the writer divided the students into groups of three or four and had each student in the groups alternately lead the activities. When the class finished reading one text, the writer sometimes gave a summary writing assignment to students. The writer also encouraged students to use the strategies outside the classroom so that the training could be transferred to other reading tasks. The remaining eleven reading texts were taught following the same procedure.

\subsection{Analysis}

The experimental data were subjected to two-way analysis of variance (ANOVA). One day prior to the onset of the training, all subjects were given a reading comprehension pre-test. Fourteen weeks later, when the subjects finished the 42-hour-long training, all subjects were given the same reading comprehension test as a post-test. The rationale for using exactly the same test for both pre- and posttesting was to assure an exactly comparable test, thus avoiding the problem of equating different forms of pre-test and post-test.

The fourteen-week interval between administration was deemed long enough to control for any short-term memory effect; since subjects were not provided with the correct answers after the pre-test, even were they to remember how they had answered a question the first time, they had no way of knowing whether that answer was correct. Moreover, any effects due to experience with the test would be 
comparable for each of the three groups. And, finally, one of the most common types of test reliability in psychometrics consists of such test-retest reliability.

\section{RESEARCH FINDINGS AND DISCUSSIONS \\ 4.1 Research Findings}

The researcher conducted the classroom action research by using peer learning strategy to solve the students problem as well as improving students' reading comprehension. After that the researcher computed the students' individual score to 10 obtain the mean score. This research was conducted by pretest and post test. In this chapter, the writer presents the research findings and its discussion. The descriptions are as follows:

\section{Pre-Test}

The researcher started the lesson by giving brainstorming to the students by asked the students about their experience in reading text and asked them to mention the title of text they had read. Then, the researcher asks the students to do the pre-test. The researcher should help the students to manage the time. The researcher administers the essay test to measure the student's comprehension. The students worked individually. The researcher monitored the students in their individual working. Some students seemed find some difficulties in doing the test. The researcher had to pay more attention in monitoring the students in their individual work, because there are some students were cheating in the test. In the first cycle, the students did not gain good result. The mean score of students 'competence in comprehend the reading text is $37 \%$ whopassed the test. It was categorized as poor to average. This point showed that the students' comprehension in reading was low.

\section{Post-Test}

On the Post-test, the researcher reviewed the material on the pre-test. The researcher explained the generic structure and the elements of text. After that the researcher explained how to apply peer learning strategy. The researcher had all the students' attention in the second meeting.
All of the students were ready to start the lesson, so all the students could pay attention to the researcher's explanation. The researcher asked the students to implement the peer learning strategy. The students can manage the time, so the problem of time management in the activity was solved. The researcher administers the essay test to measure the student's comprehension. The students worked individually. The researcher monitored the students in their individual working. It seemed that the students could do the task easily. The students' mean score in the second cycle was $77,33 \%$. It was categorized "average to good".

\subsection{Discussion}

This research was conducted in pre-test and post-test. After the pre-test the study consist of planning stage, acting stage, observing stage, and reflecting stage. The acting stages were conducted in one meeting (90 minutes) that was performed during the teaching-learning process. While doing teaching learning process. The problems of the students in reading narrative text were as follows:

1. The students could not find the details information of the text given very well.

2 . The students could not find the main idea from each paragraph from the text given by the researcher.

3. The students could not find the moral value or lesson from the text given by the researcher.

In the pre-test, the students could not find the moral value of text, the students also could not determine the main idea from each paragraph, and most of the students still faced difficulties in finding the information from the text. In conducting the post-test, a familiar topic was chosen for the students. The researcher also actively monitored the students' activity in implementing the peer learning strategy. $\mathrm{He}$ ensured that all the students answered the questions by themselves. The students were more active and enjoy during the teaching learning process in implementing the peer learning strategy. All students could finish the tasks and the researcher could give a 
chance for the students to share their difficulties during the teaching-learning process and then the researcher concluded the materials. After observing the process and interpreting the data, both the researcher decided to stop the actions because the data showed that the indicators of success were fulfilled.

The researcher compute the students' individual score and the mean score. The research finding showed that the students' mean score in the pre-test was 33\% eho passed the test. It was qualified "Poor to Average".. In the post-test the students' mean score was $77,33 \%$ who passed the test it was qualified "average to good". By applying peer learning strategy, the students can divide the story into separate components and events. The researcher believes that it is a good strategy to build their comprehension. It is a focused method and it encompassed the broader context of developing understanding of an entire story. At every stage of the peer learning, the students were able to provide accurate information, which was good evidence that they had developed a complete understanding of the story. Peer learning strategy could improve the students' interpretative abilities by enabling them to visualize story characters, events and setting and also increase students' comprehension of selections by organizing and sequencing main story events. The students were encouraged to actively interact with the material while reading by the organized techniques. It also leads to a more active learning environment, and deeper processing of information. In conclusion, the research findings of the research were satisfying. The student's comprehension of text was improved by implementing the teaching strategy. In the teaching learning process, the students were able to do basic components of the story such as setting, problem, goals, action, and outcomes. The peer learning provides structure and organization so students could comprehend the story more effective, it did not seem that the students read the story only for answering question and getting mark, but more than that, the students showed their interest in reading. The action research hypothesis was accepted.

\section{CONCLUSIONS AND SUGGESTIONS}

\subsection{Conclusions}

Based on the analysis of the students' learning, the researcher described the conclusions as: (1) Students' reading comprehension of text was improved by applying the teaching techniques. The mean score increased from $37 \%$ to $77 \%$ (2) this research was conducted in two steps with four stages - Planning, acting, observing, and reflecting. In the pre-test, the indicators of success were still not fulfilled. In posttest the indicator of success were fulfilled and the action was stopped, (3) Peer learning in reading strategy were able to make the students active in the teaching learning process. They were able to do the basic components of the story such as setting, problem, goals, action, and outcomes. The peer learning provides structure and organization so students could comprehend the story more effectively.

\subsection{Suggestions}

Peer learning for reading strategy should be a strategy for English researchers in teaching. It was useful to improve the students' reading comprehension of text. It could help the students understanding the elements of the text, finding the main idea and the moral value of a text. To make sure the teaching learning runs well, the researcher should explain clearly about peer learning strategy before starting the teaching learning process.

\section{BIBLIOGRAPHY}

Baker, L., \& Brown, A. (1984). Metacognitive skills and reading. In D. P. Pearson (Ed.), Handbook of reading research (pp. 353-394). New York: Longman.

Barnett, M. A. (1988). Reading through context: How real and perceived strategies use affects L2 
comprehension. Modern

Language Journal, 72, 150-162.

Bereiter, C., \& Bird, M. (1985). Use of thinking aloud in identification and teaching of reading comprehension strategies. Cognition and Instruction, 2, 131-156.

Block, E. (1986). The comprehension strategies of second language readers. TESOL Quarterly, 20, 163-494.

Block, E. (1992). See how they read: Comprehension monitoring of $\mathrm{LI}$ and $L 2$ readers. TESOL Quarterly, 26, 319-342.

Brown, A., \&Palincsar, A. (1984). Reciprocal teaching of comprehension-fostering and comprehension monitoring activities. Cognition and Instruction, 1(2), 117-175.

Carrell, P. L. (1985). Facilitating ESL reading by teaching text structure. TESOL Quarterly, 19, 727-752.

Carrell, P. L. (1989) Metacognitive awareness and second language reading. Modern Language Journal, 73, 120-133.

Carrell, P., Pharis, B. G., \&Liberto, J. C. (1989). Metacognitive strategy training for ESL reading. TESOL Quarterly, 23(4), 646-678.

Dansereau, D. (1985). Learning strategy research. In J. Segal \& S.
Chipman (Eds.), Thinking and learning skills. London: Lawrence Erlbaum Associates.

Garner, R. (1980). Monitoring of understanding: An investigation of good and poor readers' awareness of induced miscomprehension of text. Journal of Reading Behavior, 12, 55-63.

Garner, R. (1987). Metacognition and reading comprehension. Norwood, NJ: Ablex Publishing.

Gaskins, I. (1994). Classroom applications of cognitive science: Teaching poor readers how to learn, think, and problem solve. In K. McGilly (Ed.), Classroom Lessons: Integrating cognitive theory and classroom practice (pp. 129-154). Cambridge, MA: The MIT Press.

Hosenfeld, C. (1977). A preliminary investigation of the reading strategies of successful and nonsuccessful second language learners. System, 5, 110-123.

Janzen, J. (1996). Teaching strategic reading. TESOL Journal, 6(1), 6-9.

Weinstein, C., \& Underwood, V. (1985). Learning strategies. In J. Segal \& S. Chipman (Eds.), Thinking and learning skills. London: Lawrence Erlbaum Associates. 